\title{
Manufacturing Compost and Biochar from Cow Manure in Buduk Village, Badung, Bali
}

\author{
Yohanes Parlindungan Situmeang and Made Suarta \\ \{ypsitumeang63@gmail.com\}
}

\author{
Agrotechnology Study Program, Faculty of Agriculture, Warmadewa University
}

\begin{abstract}
The poor management of livestock waste products, problems associated with the technology transfer of compost and biochar organic fertilizers not performed in partners, and management issues related to group strengthening are some of the problems found in partners in Buduk village, Badung Bali. The purpose of community service activities is to increase the understanding and skills of partners in converting livestock waste into compost and biochar organic fertilizers that are useful for improving soil fertility and crop yields. The integration of livestock business as a meat producer with its byproducts processed into fertilizer that is ready to be marketed is expected to increase the added value and income of farmers. Therefore, these goals were achieved through counseling, training, mentoring, and technology transfer with direct practice in the field. The results showed that the partner farmer groups tend to receive and implement management of cow manure waste which is immediately processed into environmentally friendly organic fertilizer. They are also able to accept and apply technology to make compost and biochar organic fertilizers that are ready to be marketed. The results also showed that PKM is used by local governments to integrate livestock waste management with the production of organic fertilizer that is ready to be marketed to improve less fertile agricultural land and increase agricultural crop yields.
\end{abstract}

Keywords: Farmers, cow manure waste, compost, biochar

\section{Pendahuluan}

Luas wilayah Desa Buduk adalah adalah 363,46 Ha, dengan tanah perumahan/lahan kering 182 Ha serta sawah luas 181 Ha. Desa Buduk dibatasi oleh Desa Dalung Kecamatan Kuta Utara disebelah Timur, Desa Tumbakbayuh disebelah selatan, Desa Cepaka Kecamatan 
Kediri Tabanan disebelah Barat dan Kelurahan Kapal disebelah utara. Desa Buduk berada pada ketinggian $16 \mathrm{~m}$ dari permukaan laut

Desa Buduk dibagi menjadi sepuluh Banjar Dinas yang mana nama-nama Banjar Dinas tersebut sesuai dengan asal-usul/sejarah Desa Buduk itu sendiri yaitu seperti: Banjar Dinas Gunung, Banjar Dinas Umekepuh, Banjar Dinas Umecandi, Banjar Dinas Umetegal, Banjar Dinas Pasekan, dengan Kelian Dinasnya I Made Nayi, Banjar Dinas Sengguan, Banjar Dinas Tengah, Banjar Dinas Kaja, Banjar Dinas Tampakkerep, danBanjar Dinas Bernasi.

Potensi pertanian di subak legena desa buduk cukup tinggi. Dari luas potensi panen 55 ha dipanen seluas 55 ha pula. Padi yang dipanen adalah varietas Ciherang dengan produktivitas 6.53 ton/ha. Sedangkan potensi peternakan di desa buduk cukup menjanjikan, tersedianya bahan pakan hijauan yang berasal dari sisa panen maupun dari padang rumputrumputan membuat masyarakat setempat mulai melirik ke usaha ternak sapi. Para petani dan peternak di desa buduk pada tahun 2009 membentuk suatu kelompok yang bernama Kelompok Tani Ternak Giri Bhuana Sari, dengan jumlah anggota 20 orang dan 10 ekor sapi.

Ternak sapi adalah peluang usaha ternak di desa yang luar biasa menguntungkan pada saat lebaran haji. Sapi adalah jenis daging yang tingkat permintaanya sangat tinggi, sehingga seringkali pemerintah harus impor. Ternak sapi bukan jenis usaha dengan modal kecil, namun usaha ternak ini memerlukan modal yang besar. Harga bibit sapi, pembuatan kandang, dan kebutuhan pakan ternak yang harus selalu tersedia membutuhkan modal yang besar. Usaha ternak sapi ini sangat prospek dan menjanjikan keuntungan besar dari penjualan sapi maupun dari hasil samping berupa limbah kotoran ternak sapi yang dapat diolah menjadi pupuk organik kompos dan produk lainnya seperti biochar dan biogas.

Harapan mitra selama ini adanya transfer teknologi dari pihak akademisi yang dapat membantu mereka dalam proses pembuatan kompos dan biochar sehingga nantinya mereka dapat memproduksi kompos dan biochar sendiri. Dengan transfer teknologi diharapkan produksi dan kualitas kompos dan biochar semakin meningkat, kesinambungan produksi pupuk organik mereka dengan sendirinya akan dapat meningkatkan pendapatan ekonomi masyarakat desa buduk.

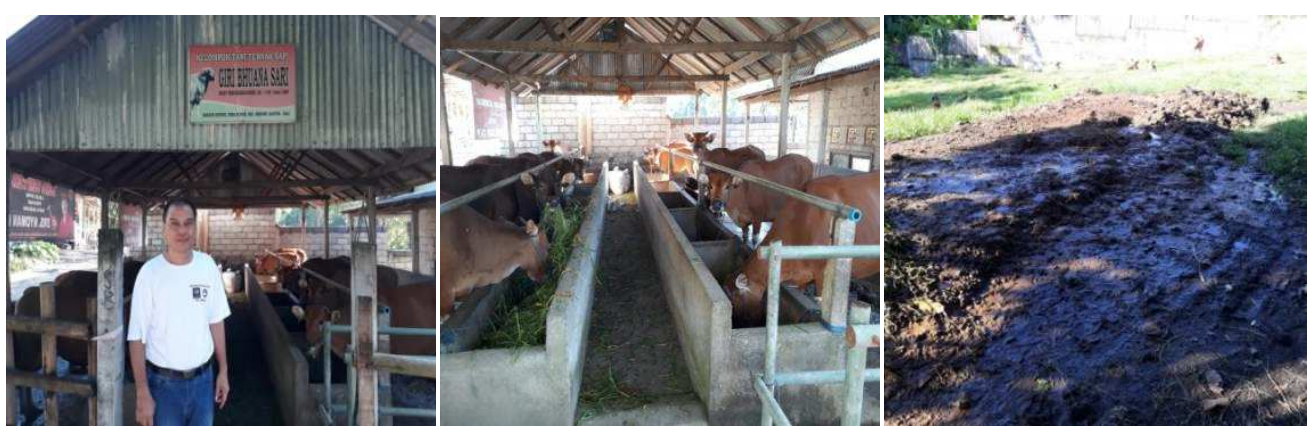

Gambar 1. Gambaran Kondisi Mitra

Dalam usaha ternak, hasil sampingan berupa limbah kotoran sapi sering menjadi masalah serius di sekitar lingkungan kandang, terutama dari bau yang tak sedap yang dapat berdampak 
terhadap kesehatan manusia. Oleh karena itu, limbah ternak ini harus dikelola dengan baik dengan cara memprosesnya menjadi produk yang bermanfaat dan memberikan nilai tambah bagi peternak serta dapat meningkatkan taraf hidup peternak. Limbah ternak ini umumnya dapat diolah menjadi berbagai produk organik, seperti pupuk kandang (sudah matang), kompos, biochar, biourine, dan biogas. Manfaat kompos dan biochar ini bila diapilkasikan ke lahan pertanian dapat memperbaiki kesuburan tanah dan meningkatkan hasil tanaman $[1,2]$ Situmeang 2015, Situmeang 2018). Kelompok mitra ini awalnya hanya memiliki sapi 10 ekor, yang mana dalam perkembangannya saat ini sudah mencapai 20 ekor sapi. Kelompok ini masih belum mampu memproduksi pupuk organik kompos dan produk lainnya, walaupun di kelompok sudah tersedia sarana bangunan tempat penampungan dan pengolahan pupuk serta mesin pengolahan pupuk sederhana namun belum dimanfaatkan oleh kelompok secara maksimal. Tata cara tradisional yang mereka terapkan selama ini harus diubah kearah yang lebih profesional melalui pemberdayaan petani kelompok mitra agar memiliki kemampuan dan ketrampilan cara memproduksi pupuk organik kompos dan produk lainnya. Berdasarkan hal tersebut maka kami melakukan pendampingan, pelatihan dan transfer teknologi pembuatan kompos dan biochar berbasis limbah kotoran sapi di kelompok atau mitra.

\section{Metode Pelaksanaan}

Pelaksanaan pengabdian masyarakat diselenggarakan di kelompok tani ternak Giri Bhuana Sari di Banjar Gunung Desa Buduk Kecamatan Mengwi, Kabupaten Badung Provinsi Bali. Pengabdian ini berlangsung dari bulan Juli hingga September 2019.Metode pelaksanaan program PKM pembuatan pupuk organik kompos dan biochar dilakukan dengan kegiatan sosialisasi, pendampingan, pelatihan, dan transfer teknologi. Pendampingan dilakukan terhadap 10 anggota kelompok ternak. Pelaksanaan PKM ini mencakup kegiatan: (1). Sosialisasi program PKM, (2). Transfer teknologi pembuatan pupuk kompos dan biochar. (3) Praktek pembuatan pupuk kompos, dan (4) Praktek pembuatan biochar (5) Evaluasi akhir terhadap materi pengabdian yang telah diberikan pada kelompok, mulai dari proses penjajagan, sosialisasi, pendampingan hingga dilaksanakannya transfer paket teknologi pembuatan pupuk organik kompos dan biochar sehingga petani mitra dapat meningkatkan kemampuan, ketrampilan, dan nilai tambah produk serta peningkatan pendapatan kelompok tani ternak di desa Buduk.

\section{Hasil Dan Pembahasan}

Pelaksanaan PKM ini telah berjalan sesuai rencana, kegiatan diawali dengan melakukan sosialisasi program kepada kelompok mitra melalui pertemuan kelompok, penyuluhan dan pelatihan, serta transfer teknologi atau praktek langsung di mitra. Adapun hasil pelaksanaan kegiatan PKM sebagai berikut:

\subsection{Pengenalan dan penyuluhan serta pelatihan pembuatan pupuk kompos}


Pada tahap ini diperkenalkan cara pengolahan limbah kotoran sapi hingga menjadi pupuk kompos. Penyuluhan pembuatan pupuk kompos kepada para peserta dilakukan di rumah mitra (Gambar 2). Penyuluhan ini diikuti oleh 10 orang anggota mitra. Pada penyuluhan ini juga diberikan materi berupa liflet.
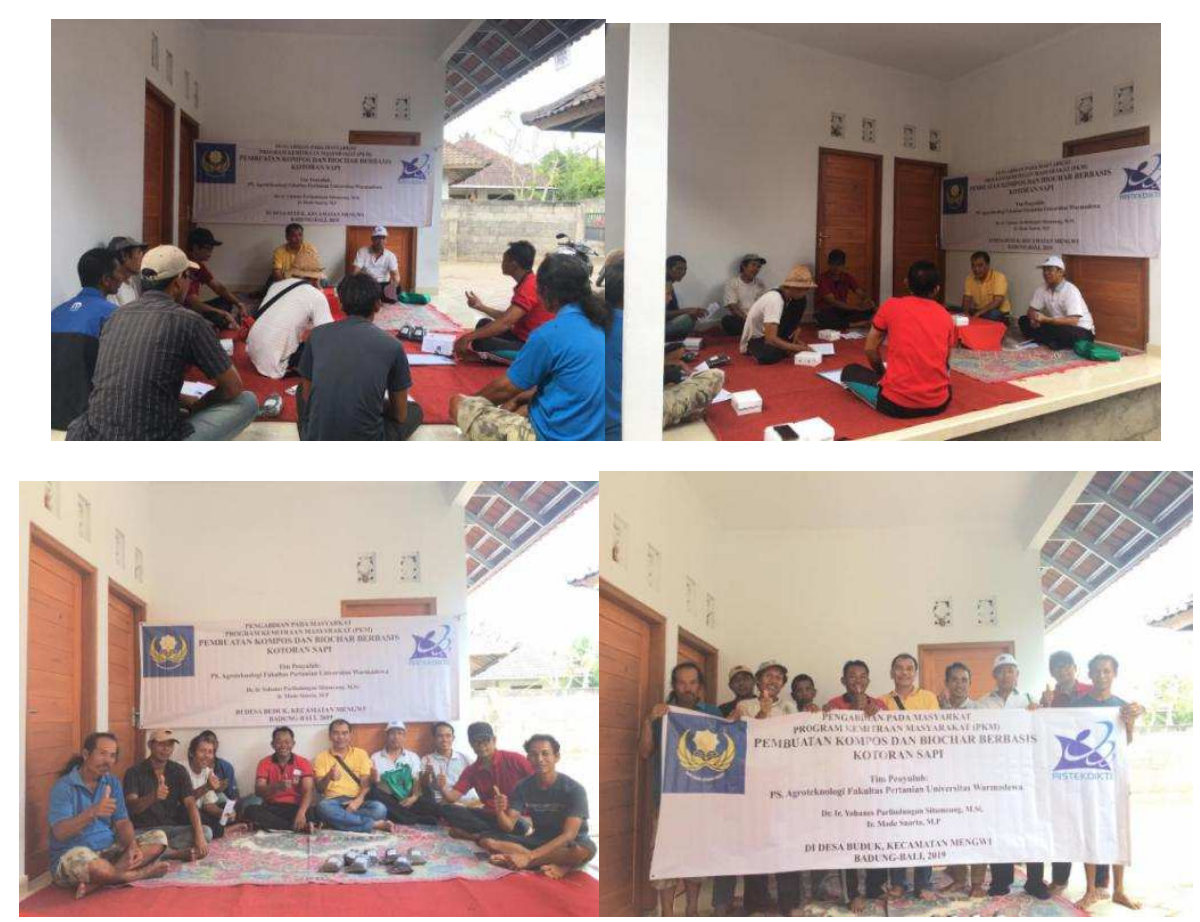

Gambar 2. Penyuluhan dan pelatihan pembuatan kompos dan biochar

\subsection{Transfer Teknologi Pembuatan Pupuk Kompos}

Kompos merupakan hasil fermentasi dari bahan-bahan organik seperti sisa tanaman, kotoran hewan atau limbah organik lainnya [3]. Kompos dapat dibuat dari berbagai macam bahan organik, antara lain dari kotoran sapi yang mengandung unsur hara $\mathrm{N}$, P, dan $\mathrm{K}$ yang tinggi [4]. Kompos dapat memperbaiki struktur tanah, memperbaiki sifat fisik, kimia, dan biologi tanah, meningkatkan daya ikat antar partikel tanah, dan antar partikel tanah dengan air sehingga akan meningkatkan kemampuan tanah untuk menahan air tanah $[5,6,7]$.

Setelah penyampaian materi, disiapkan bahan dan alat yang diperlukan untuk memproduksi kompos, selanjutnya dilakukan transfer teknologi pembuatan kompos langsung kepada peserta di lokasi kandang sapi (Gambar 3 dan 4). Dari kegiatan ini, kelompok sasaran telah mampu memproduksi pupuk organik kompos berbasis kotoran sapi yang berkualitas serta dapat diterapkan di kelompok tani ternak dan dijual ke pasar yang dapat memberi nilai tambah bagi kelompok. 
Bahan yang digunakan:

1. Kotoran sapi $60 \mathrm{~kg}$,

2. Serbuk gergaji / sekam padi $10-30 \mathrm{~kg}$,

3. Abu sekam / abu dapur 10-30 kg,

4. Kapur pertanian (dolomit) $1 \mathrm{~kg}$,

5. EM4 $100 \mathrm{ml}$,

6. Molasis $100 \mathrm{ml}$ (sebagai pengganti bisa gula merah/gula putih)

7. Ember.

Tahapan pembuatan Kompos:

1. Untuk pembuatan $100 \mathrm{~kg}$ kompos, campur kotoran sapi sebanyak $60 \mathrm{~kg}$, serbuk gergaji/ sekam/ jerami padi/daun gamal sebanyak $30 \mathrm{~kg}$, abu dapur/abu sekam/ arang sekam sebanyak $10 \mathrm{~kg}$.

2. Kemudian siramkan campuran EM4 $100 \mathrm{ml}$ dan molasis $100 \mathrm{ml}$ yang telah dilarutkan dalam 5-10 liter air hingga bila diperas dengan tangan bahan tersebut akan terperas sedikit air.

3. Bahan tersebut kemudian ditutup dengan menggunakan terpal atau bisa juga dimasukkan dalam karung goni atau tong plastik.

4. Setiap 1 minggu sekali dibalik, difermentasi selama 21 hari.

5. Aktivitas mikroba bisa ditandai dengan adanya peningkatan suhu. Biasanya peningkatan suhu terjadi menjelang hari ke 8 sampai hari ke 21 .

6. Setelah 21 hari dibuka, kemudian dijemur diberi kapur pertanian.

7. Setelah pengomposan selesai, lalu perkecil ukuran dengan memperhalus bentuk,

8. Lakukan pengemasan.

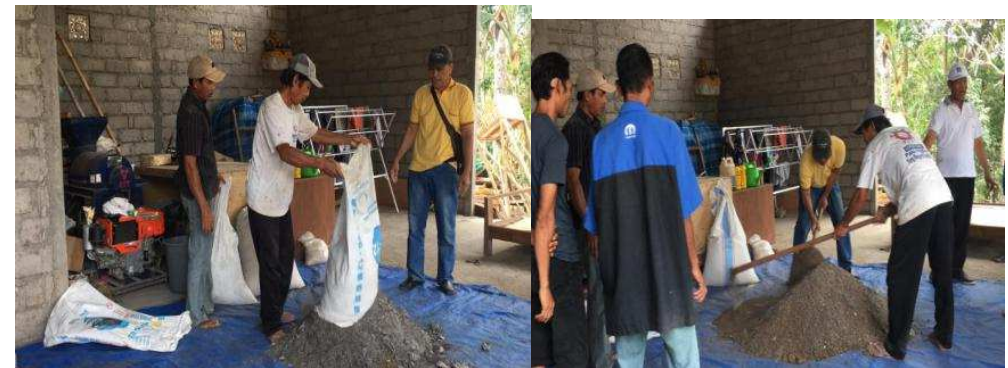




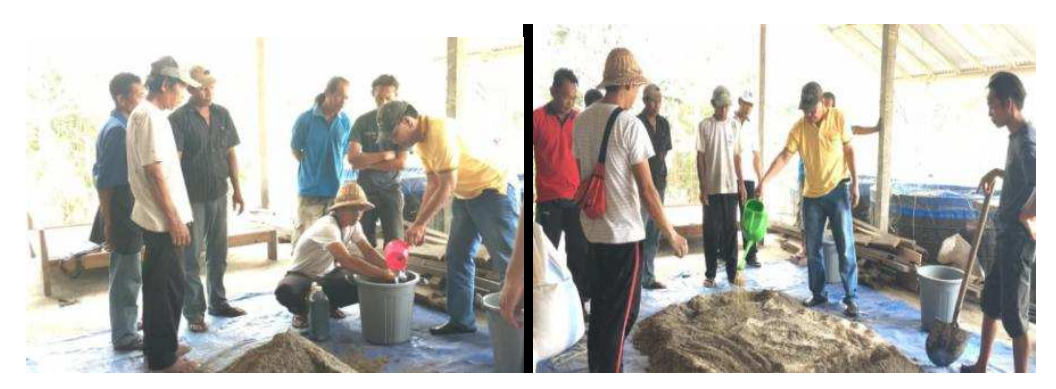

Gambar 3. Praktek pembuatan pupuk kompos

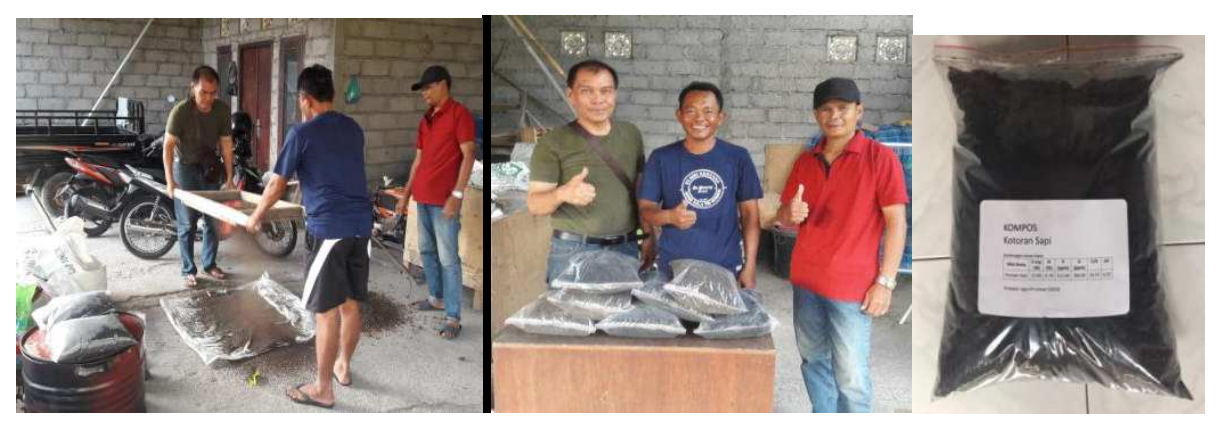

Gambar 4. Pengayakan kompos hasil fermentasi hingga pengemasan

\subsection{Transfer teknologi pembuatan biochar}

Pada tahap ini diperkenalkan cara pengolahan limbah kotoran sapi hingga menjadi biochar. Pengenalan dan penyuluhan pembuatan biochar kepada para peserta dilakukan di rumah mitra (Gambar 5). Pada penyuluhan ini juga diberikan materi berupa liflet. Transfer teknologi pembuatan biochar dapat berlangsung sesuai rencana dan petani ternak di mitra telah mampu menerima dan menerapkan tenologi pembuatan biochar hingga pengemasan.

Pembuatan biochar dilakukan dengan menggunakan alat pembakaran atau pirolisator suhu 250-350 ${ }^{\circ} \mathrm{C}$ selama 2,0-3,5 jam, akan menghasilkan arang yang mengandung karbon tinggi dan dapat diaplikasikan sebagai pembenah tanah [8]. Proses pembakaran tidak sempurna biomassa limbah pertanian yang menghasilkan biochar dapat digunakan sebagai pembenah tanah untuk mengikat karbon, menghasilkan serat yang baik dan arang yang sangat porous yang membantu tanah menahan hara dan air [9]. Pemanfaatan biochar pada skala kecil di pedesaan, sebagai pembenah tanah dan sumber energi perlu dikembangkan secara lebih luas untuk peningkatan produktivitas lahan dan tanaman pertanian, serta mengurangi efek negatif terhadap kerusakan lingkungan [10]. 
Bahan yang digunakan:

1. Kotoran padat sapi yang kering,

2. Drum pembakar kotoran sapi

3. Kayu bakar

4. Alat penghancur arang

5. Ayakan 20 - 50 mesh

6. Pengemas

Tahapan pembuatan biochar:

1. Kumpulkan $100 \mathrm{~kg}$ limbah kotoran sapi dan jemur hingga kering.

2. Masukkan kotoran sapi kering pada drum pengarangan sesuai kapasitas nya.

3. Nyalakan tungku kayu bakar.

4. Aduk kotoran, jika sudah mulai terjadi proses pengarangan segera lakukan pengadukan hingga merata terbentuk arang.

5. Setelah terbentuk arang hancurkan menjadi butiran kecil lalu ayak hingga terbentuk butiran seragam

6. Kemudian lakukan pengemasan. 

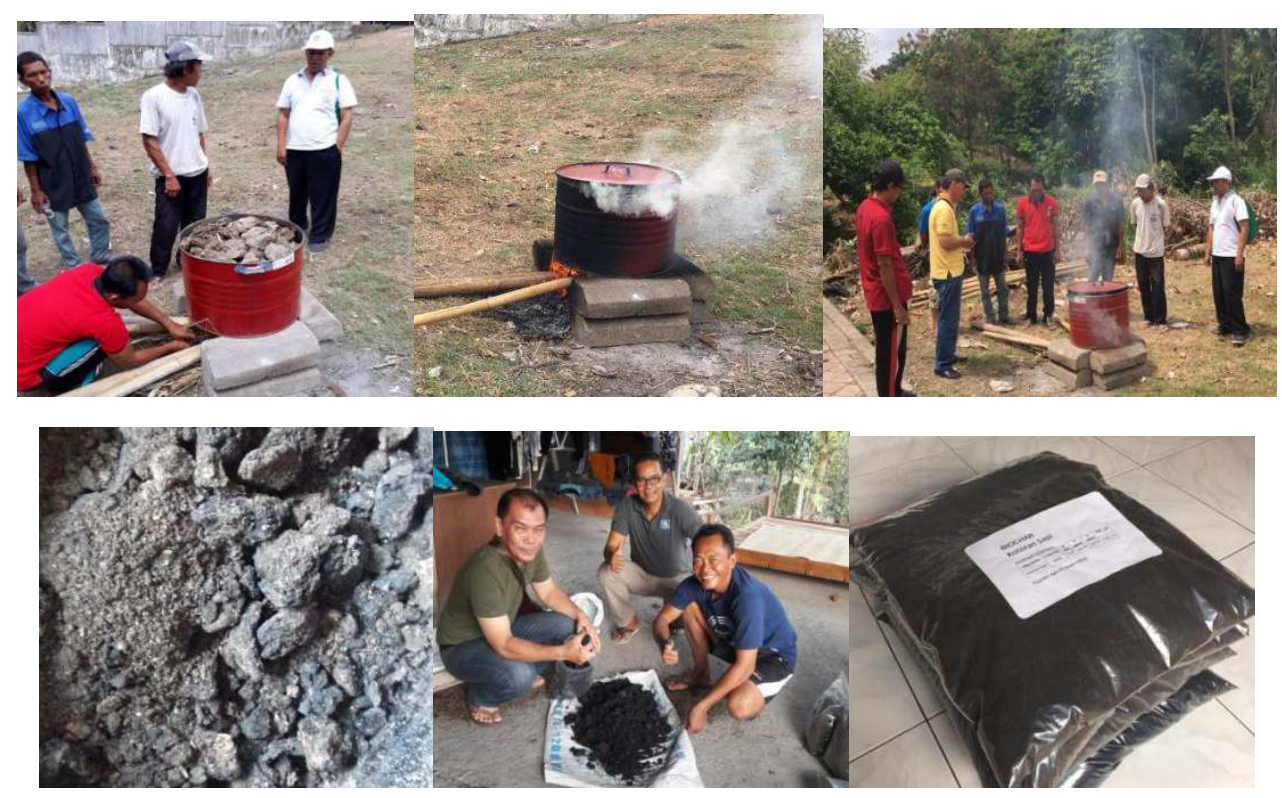

Gambar 5. Praktek pembuatan biochar hingga pengemasan

\section{Kesimpulan}

Kegiatan pengabdian yang dilakukan melalui pendampingan dan pelatihan di kelompok mitra dapat disimpulkan bahwa kelompok tani ternak di mitra telah mampu membuat pupuk organik kompos dan biochar berbasis limbah kotoran sapi. Kelompok tani ternak juga telah mampu menerima dan menerapkan transfer teknologi pembuatan pupuk organik kompos dan biochar hingga menghasilkan produk kompos dan biochar dalam kemasan yang siap dipasarkan dan digunakan untuk memperbaiki kesuburan tanah dan hasil tanaman pertanian.

\section{Ucapan Terima Kasih}

Terima kasih kepada semua pihak yang telah membantu kegiatan PKM ini. Kepada ketua LPM dan Rektor Unwar atas bantuan hibah pengabdian institusi yang telah kami gunakan untuk kegiatan PKM ini. Terima kasih kepada kelompok tani ternak Giri Bhuana Sari di Desa Buduk yang telah bersedia menjadi mitra pengabdian kami. 


\section{References}

[1] Situmeang, Y. P., Adnyana, I. M., Subadiyasa, I. N. N., \& Merit, I. N. 2015. Effect of Dose Biochar Bamboo, Compost, and Phonska on Growth of Maize (Zea mays L.) in Dryland. International Journal on Advanced Science, Engineering and Information Technology, 5(6), 433439.

[2] Situmeang Y P, Adnyana I M, Subadiyasa I N N, and Merit I N 2018. Effectiveness of Bamboo Biochar Combined with Compost and NPK Fertilizer to Improved Soil Quality and Corn Yield. International Journal on Advanced Science, Engineering and Information Technology, 8(5), 2241-2248.

[3] Indriani, Y.H. 2008. Membuat Kompos Secara Kilat. Penebar Swadaya. Jakarta

[4] Atmojo, S.W. 2003. Peranan Bahan Organik terhadap Kesuburan Tanah dan Pengelolaannya. Universitas Sebelas Maret Surakarta. Solo

[5] Setyorini, D., Saraswati, R., Anwar, E. K.. 2008. Kompos. Pupuk Organik dan Pupuk Hayati. Hal 11-37

[6] Prihandini, P.W., dan Purwanto, T. 2007. Petunjuk Teknis Pembuatan Kompos Berbahan Kotoran Sapi. Pusat Penelitian dan Pengembangan Peternakan.

[7] Isroi, 2008. Kompos. Balai Penelitian Bioteknologi Perkebunan Indonesia, Bogor. www.isroi.org

[8] Badan Penelitian dan Pengembangan Pertanian, 2012. Pembenah Tanah Biochar. Balai Penelitian Tanah. Kementerian Pertanian Republik Indonesia. [cited 2012 Des. 11]. URL: http://puslitklaten.wordpress.com/pembenah-tanah-biochar

[9] International Biochar Initiative, 2012. What is Biochar?. www.biochar-international. org

[10] Gani, A. 2018. Potensi Arang Hayati Biochar Sebagai Komponen Teknologi Perbaikan Produktivitas Lahan Pertanian. Iptek Tanaman Pangan 4(1): 33-48 